\title{
Ecological drought resistance and adaptability of apple varieties
}

\author{
Nemeskéri ${ }^{1}$, E., Sárdi ${ }^{3}$, É., Szabó ${ }^{4}$, T. \& Nyéki ${ }^{2}$, J. \\ ${ }^{1}$ University of Debrecen Centre for Agricultural Sciences and Engineering, Institute of Horticultural Sciences, \\ Debrecen, HungaryE-mail: nemeskeri@agr.unideb.hu \\ ${ }^{2}$ University of Debrecen Centre for Agricultural Sciences and Engineering, Institute for Research and \\ Development, Debrecen, Hungary \\ ${ }^{3}$ Corvinus University of Budapest, Faculty of Horticultural Science, Department of Genetic and Plant Breeding, \\ Budapest, Hungary \\ ${ }^{4}$ Research and Extension Centre for Fruit Growing, Újfehértó, Hungary
}

\begin{abstract}
Summary: For adequate yields in apple plantations, during the long growing period of the fruit primordia, one of the decisive factors is water supply. Indicators of stress are valuable signs for the diagnosis of drought and necessity of watering, i.e. planning the irrigation of plantations. The aim of the present study was to find reliable signs of water stress on apple trees and at the same time conclude on the drought tolerance of different varieties. The plantation of apple varieties grafted on various stocks and cultivated according to different systems (irrigated, non irrigated, integrate and biological) has been examined continuously by leaf analysis. Along the period of growing fruits, measurements were made in the field, then the leaf samples were analysed in the laboratory for composition of pigments, carbohydrates and antioxidants, as well as the histology of the tissues checked. Without irrigation, the mean leaf mass and the relative chlorophyll content (SPAD) of the variety Idared on M4 stocks increases beyond the values of 50 SPAD, whereas on M26 stock and integrated system, it declines. In the collection of varieties, grown according to the „,integrated” system, during the development of fruits, 'Gála' and 'Remo' varieties have been affiliated to the "less susceptible" group regarding drought tolerance because of the leaf morphology, structure and content of SPAD and antioxidants. However, 'Idared' and 'Jonagold' belong to the "susceptible" group. To the same group are ranged the 'Akane, Red Rome van Well, Pink Lady' varieties. Those varieties reacted to a short period of drought by increased production (content) of carbohydrates. Regarding changes of carbohydrate content 'Greensleeves' and 'Ozark Gold' varieties belong to the moderately water dependent (requiring) group. In the field, SPAD-tests facilitated the measurement of nutrient-uptake and incorporation, which is proved by the tight correlation between the data of SPAD and the increment of leaf weight $(r=0.76-r=0.88)$, however, this depends on the variety too. SPAD is an indicator of water supply and is related with the density of stomata, cannot used for the selection of water-exigent varieties but for (drought) tolerant ones. In integrated culture, the (drought) susceptible varieties display (water-soluble) hydrophilic and lipophilic antioxidants (ACW and ACL resp.) the quantity of which may have some role in drought tolerance.
\end{abstract}

Key words: apple, drought tolerance, SPAD, carbohydrates, antioxidants

\section{Introduction}

In the intensive apple plantations, which are multiplied nowadays on a worldwide scale, water supply became a limiting factor. The dwarfing stocks are especially compromised by their shallow root system. The restriction of uptake of nutrients impairs the fruit size and yield. In apple plantations, the critical period of fruit development is most susceptible. Lack of water is responsible for the declining yields (Green et al. 2003, Caspari et al. 2004). Poor water supply diminishes the uptake of nutrients, the leaves grow smaller, less pigmented, take a spoon form, delicate shoots, fruits develop poor colour (Zatykó, 2003).

Drought and heath coupled with strong irradiation destroy the chlorophyll of the leaves, reduces the photosynthesis. Griffin et al. (2004) proved that the relative chlorophyll content of leaves (SPAD) is coupled with tolerance to light. On the sunny part of the crown, the SPAD values as well as the content of myo-inozitol (sugar alcohol) are high being a factor of light tolerance. Other authors claim that the SPAD is positively related with the index of photochemical reaction and with the nitrogen requirement of apple (Perry \& Davenport 2007), and with the measure of the drought stress (Fanizza et al. 1991, Ommen et al. 1999), the ratio of photosynthesis and conductivity of stomata (Franca et al. 2000, Kato et al. 2004) during the drought stress. Eghball \& Maranville (1991) state that the effectiveness of utilising nitrogen and water are often associated. Chlorophyll itself also contains nitrogen, therefore the measurement of chlorophyll content shows the utilisation of nitrogen and at the same time indicate the water utilisation. During dry weather, the increment of SPAD indicates the nitrogen supply of the plant (Berzsenyi \& Lap 2003), and the changes of glucose + fructose quantities (Nemeskéri et al. 2009). 
The strategy of the plant for avoiding the adversity of drought is composed by different elements, in order to moderate the loss of water for a short run, the leaves move into a paraheliotropic position (Pastenes et al. 2005), stomata went closed, roots penetrate the deep levels of the soil. Drought tolerant plants are of different anatomic structure, leaf blades are bulky, the density of stomata is higher (Kusnyirenko, 1981). During longer periods or more severe drought induces the plants to produce more osmolytic substances as glucose, sugar-alcohols, and antioxidants (Sircelj et al., 2005, 2007). The sugars as osmolytics contribute to the stabilisation of cell membranes. Concentration of sugar-alcohols (sorbitol), glucose, fructose increase, that of sucrose diminishes due to the effect of water stress (Wang et al., 1992, 1996) other sources stated the decline of sorbitol under the pressure of heavy water stress (Sircelj et al. 2005).

There are several methods serving the measurement of the water content of plants, but their efficacy depends on the purpose of the examination (Jones, 2007). In some vegetables, one week of drought may cause visible symptoms, leaves turn yellow and flowers abscise (Nemeskéri et al., 2008). In fruit trees, only utterly heavy drought of soil and of atmosphere may cause conspicuous symptoms, e.g. the curving of leaves. The morphologically appearing signs are difficult to be observed in the field, but an easily recognisable indicator is badly needed for the purpose of a reasonable planning of watering in plantations. On the other hand, we attempted to look for indicators of genuine drought tolerance induced by intentional water stress in different apple varieties.

\section{Material and methods}

The varieties examined have been grown on different rootstocks and technologies (irrigated, dry, bio- and integrated systems).

\section{Experiment I}

In 2007 and 2009, the Research Institute Ltd. Újfehértó, the non irrigated stock plantation with 8 varieties served to check the drought tolerance. Planting design was $6 \times 4 \mathrm{~m}$. The majority of varieties were grafted to M4 stock, which is considered to be drought tolerant, the varieties were: 'Akane, Idared, Ozark Gold', and 'Red Rome van Well', then on the M26 semi-dwarfing stock 'Gála, Galaxy Gála' varieties and on the drought tolerant stock, MM106, the varieties 'Greensleeves, Pink Lady'.

\section{Experiment II}

In the years 2008-2009, four varieties stood on M26 stock: 'Gála', 'Remo', 'Idared' and 'Jonagold' are examined in the experimental farm of the Debrecen University, Debrecen-Pallag, where integrated and bio technologies were used. The rows were oriented to $\mathrm{N}-\mathrm{S}$ direction according a planting design $4 \times 1.5 \mathrm{~m}$. In 2009 , the summer was excessively dry, for the experiment $45 \mathrm{~mm}$ water has been given, in 2008 no irrigation was necessary in the intense plantation. Both experiments were planted on a humus sandy soil.

The reaction of the plants was checked by leaf-analysis. Observations in the field, laboratory tests on collected samples were performed. Content of leaf pigments, carbohydrates and antioxidants were measured, and leaf tissues examined. Samples were taken between the mid of June until end of July, when the fruits are grown in both experiments.

\section{Field examinations}

A portable SPAD 502 apparatus measured the chlorophyll content. Three trees per variety have been selected, and samples taken on each of the E, S and W side of the crown, approximately at a $1.0-1.2 \mathrm{~m}$ high level, from equally developed shoots at four times. For each sample, seven leaves, on each leaf two measurements are made. Examinations of the stomata are made immediately, chemical tests on the samples kept at $-80{ }^{\circ} \mathrm{C}$ temperature.

\section{Examination of the leaf tissues}

Histological tests are performed twice, in early June and at the end of July. Four green leaves were prepared to make cross sections for measurements in a Zeiss Axioskop and 2 microscopes. Measurements are performed on the thickness of the leaf blade, of the cuticle and of the mesophyllum along the midrib of the leaf and at the half way between midrib and margin, where the SPAD was checked. For the evaluation, Sony HyperHAD coloured digital camera and the data are processed by a picture-analyser of the DigitPlan computer.

\section{Density of stomata}

Three leaf samples per variety were taken to check the density of stomata on the abaxial (lower) side. On both sides the cuticle was stripped to see, count and measure the stomata in a light microscope at a 400 -fold magnification. The density is expressed by the number per square $\mathrm{mm}$. Every measurement is noted in 4 replicates.

\section{Determination of carbohydrates and identification}

Fresh leaves were put into liquid nitrogen, frozen and homogenised, extracted by methanol: water $(80: 20 \mathrm{~V} / \mathrm{V})$. Centrifuging the suspension at $1500 \mathrm{~g}$ revolution for 10 minutes at $-1{ }^{\circ} \mathrm{C}$ temperature. The clear supernatant was analysed by chromatography (OPLC chromatograph OPLCNIT Co., Ltd., Budapest, Hungary). The OPLC separation was performed on TLC and HPTLC silica gel and $60 \mathrm{~F}_{254}$ plate (Merck Co.) with acetonitril:water (85:15 V/V) solvent. 
The carbohydrate fractions were dyed by anilinediphenylamine-phosphoric acid as a reagent. The densitometric evaluation was made according to Shimadzu CS-930 TLC/HPTLC scanner (Shimadzu Co., Kyoto, Japan), at $\lambda=540 \mathrm{~nm}$ wave-length (Sárdi et al., 1999). Carbohydrate content was related to the fresh weight $\mu \mathrm{g} / \mathrm{g}$.

\section{Determination of antioxidants}

Water-soluble antioxidants (Antioxidant Capacity of Water-soluble compounds $A C W$ ). After freezing and liophilisation, the samples were reduced to powder, then dissolved in bidestillated water stirring continuously during 60 second on $25^{\circ} \mathrm{C}$. The suspension centrifuged $10000 \mathrm{rpm}$ for 5 minutes at room temperature. The supernatant containing the water soluble antioxydants (ACW) are measured as compared with an ascorbinic acid standard PHOTOCHEM (Analytik Jena AG Germany) as a chemoluminometer apparatus.

Lipophilic (fat-soluble) antioxidants are determined (Antioxidant Capacity of Lipid-soluble Compounds ACL). The preparation of samples is similar to the former (ACW), the dry powder is dissolved in methanol and the standard solution is $\lambda$ tocoferol. Both type of antioxidants (ACW, ACL) are related to the dry matter content in units of $\mu \mathrm{g} / \mathrm{mg}$.

\section{Statistical evaluation}

The correlations between SPAD data measured in the fruit trees, the structure of the leaf, density of stomata and data of measurements in the laboratory (carbohydrates, antioxydants) have been calculated in order to develop a method for determining the drought tolerance. The statistical evaluation was performed always with the SPSS program, with variance-analysis and regression-analysis.

\section{Results}

\section{Experiment I without irrigation}

In the stock plantation of Újfehértó, there was little precipitation during the slow growth of fruits (June 12 - July 24), in 2007 and 2009. No watering has been made, therefore a moderate drought (June 12 - July 2) then a sever drought (July 2 - July 24) ensued.

In 2007, chlorophyll content of leaves (SPAD) was higher than in 2009 regarding all the three position of leaves $(\mathrm{E}, \mathrm{S}$, $\mathrm{W}$ side of the crown). The SPAD values of the eastern side were lower significantly than on the S and W side. In 2009, no difference was in SPAD measured between the east and west side, but the SPAD grew after the start (June 10), and the density of stomata increased. 'Ozark Gold' and 'Galaxy' varieties had smaller leaves and lowest values of SPAD amongst the varieties (Table 1). Highest values of SPAD are measured in 'Idared' and 'Greensleeves', and largest (heaviest) leaves appeared in 'Greensleeves'. 'Gála' was with means of SPAD values (45-46) able to produce large (heavy) leaves, which is interpreted with a favourable uptake of nutrients. The most density of stomata was measured on trees grafted on M4 stocks in 'Red Rome Van Well' varieties, on M26 stock 'Gála' and on MM106 stock “Greensleeves'.

\section{Morphological changes}

With the progress of drought, at the end of July (July 24), visible symptoms of drought appeared. Leaves of 'Ozark Gold' turn to light yellowish green, 'Idared' leaves twisted, whereas 'Akane', 'Red Rome van Well' got yellow leaves. The thickness of leaves at the mid rib, at the half of the length, the intercellular space was different between varieties and during the progress of drought. Substantial thickening of the leaf blade was registered in 'Akane' compared with status

Table 1. Relative chlorophyll content (SPAD) and stomata density of apple leaves during fruit development non-irrigated conditions

\begin{tabular}{|c|c|c|c|c|c|c|c|c|c|c|c|c|}
\hline \multirow{2}{*}{\begin{tabular}{|r} 
Year \\
Variety
\end{tabular}} & \multicolumn{4}{|c|}{2007} & \multicolumn{4}{|c|}{2009} & \multicolumn{4}{|c|}{ Average of years } \\
\hline & $\begin{array}{c}\text { Leaf } \\
\text { weight } \\
\mathrm{g} \\
\end{array}$ & SPAD & $\begin{array}{c}\text { Stomata } \\
\text { piece/ } \\
\mathrm{mm}^{2}\end{array}$ & $\begin{array}{l}\text { Stomata } \\
\text { size } \mu\end{array}$ & $\begin{array}{c}\text { Leaf } \\
\text { weight } \\
\mathrm{g} \\
\end{array}$ & SPAD & $\begin{array}{c}\text { Stomata } \\
\text { piece/ } \\
\mathrm{mm}^{2} \\
\end{array}$ & $\begin{array}{l}\text { Stomata } \\
\text { size } \mu \\
\end{array}$ & $\begin{array}{c}\text { Leaf } \\
\text { weight } \\
\mathrm{g} \\
\end{array}$ & SPAD & $\begin{array}{c}\text { Stomata } \\
\text { piece/ } \\
\mathrm{mm}^{2} \\
\end{array}$ & $\begin{array}{r}\text { Stomata } \\
\text { size } \mu \\
\end{array}$ \\
\hline \multicolumn{13}{|l|}{ M4 rootstock } \\
\hline OZARK GOLD & $0.51 \mathrm{bc}$ & $44.72 \mathrm{f}$ & $338 \mathrm{c}$ & $26.14 \mathrm{bc}$ & $0.64 \mathrm{~b}$ & $36.65 \mathrm{f}$ & $384.98 \mathrm{~b}$ & $25.82 \mathrm{~b}$ & 0.57 & 40.69 & 361.49 & 25.98 \\
\hline IDARED & $0.60 \mathrm{ab}$ & $55.12 \mathrm{a}$ & $323 \mathrm{~d}$ & $26.31 \mathrm{~b}$ & $0.60 \mathrm{~b}$ & $48.67 \mathrm{a}$ & $341.59 \mathrm{c}$ & $25.95 \mathrm{ab}$ & 0.60 & 51.90 & 332.30 & 26.13 \\
\hline AKANE & $0.48 \mathrm{c}$ & $47.56 \mathrm{e}$ & $333 \mathrm{~cd}$ & $27.14 \mathrm{~b}$ & $0.77 \mathrm{ab}$ & $46.39 \mathrm{~b}$ & $372.83 \mathrm{~b}$ & $24.32 \mathrm{~d}$ & 0.63 & 46.98 & 352.92 & 25.73 \\
\hline $\begin{array}{l}\text { RED ROME } \\
\text { VAN WELL }\end{array}$ & $0.63 \mathrm{ab}$ & $49.43 \mathrm{~d}$ & $330 \mathrm{~cd}$ & $26.01 \mathrm{bc}$ & $0.72 \mathrm{ab}$ & $45.17 \mathrm{c}$ & $431.18 \mathrm{a}$ & $26.17 \mathrm{a}$ & 0.68 & 47.30 & 380.59 & 26.09 \\
\hline \multicolumn{13}{|l|}{ M26 rootstock } \\
\hline GALA & $0.64 \mathrm{ab}$ & $45.24 \mathrm{f}$ & $336 \mathrm{~cd}$ & $26.01 \mathrm{bc}$ & $1.09 \mathrm{a}$ & $45.95 \mathrm{bc}$ & $416.32 \mathrm{a}$ & $25.29 \mathrm{ch}$ & 0.86 & 45.60 & 376.16 & 25.65 \\
\hline GALAXY & $0.48 \mathrm{c}$ & $44.53 \mathrm{f}$ & $359 \mathrm{~b}$ & $25.61 \mathrm{bc}$ & $0.64 \mathrm{~b}$ & $38.71 \mathrm{e}$ & $387.8 \mathrm{~b}$ & $26.5 \mathrm{a}$ & 0.56 & 41.62 & 373.40 & 26.06 \\
\hline \multicolumn{13}{|l|}{ MM106 rootstock } \\
\hline PINK LADY & $0.71 \mathrm{a}$ & $46.64 \mathrm{e}$ & $335 \mathrm{~cd}$ & $25.04 \mathrm{c}$ & $0.88 \mathrm{a}$ & $41.70 \mathrm{~d}$ & $369.64 \mathrm{~b}$ & $24.25 \mathrm{~d}$ & 0.79 & 44.17 & 352.32 & 24.65 \\
\hline GREENSLEEVES & $0.70 \mathrm{a}$ & $52.30 \mathrm{~b}$ & $346 \mathrm{bc}$ & $26.63 \mathrm{~b}$ & $1.03 \mathrm{a}$ & $48.57 \mathrm{a}$ & $433.15 \mathrm{a}$ & $25.55 \mathrm{~b}$ & 0.87 & 50.44 & 389.58 & 26.09 \\
\hline
\end{tabular}

Values in each column having different letters are significantly different at the $\mathrm{P}<0.05$ level using Duncan's multiple range test. 


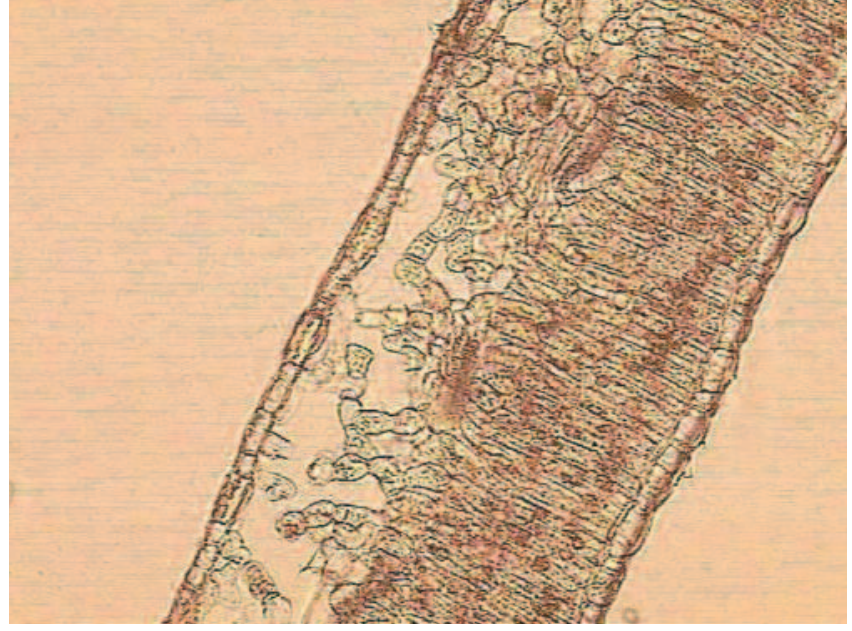

Figure 1. In the assortment without irrigation, cross section of leaf blades of Ozark Gold the large intercellular space is seen (magnification 10x)

seen in June (Table 2). 'Ozark Gold' had large intercellular space (Figure 1) and had thick cuticle at the midrib, but the water circulation was impaired by narrow tracheids of the 'Ozark Gold' leaves (Figure 2). The changes in histological structure of the 'Idared' leaves were not remarkable during the sustained drought (Table 2).

\section{Changes in carbohydrate content of leaves}

Observations in June did not show water stress (June 12), when content of sugars, glucose and fructose were high in Ozark Gold, Akane, Idared on M4 stock and Greensleeves on MM106, Galaxy on M26 stock.

A slight drought for a short time did not alter the carbohydrate content of leaves in the same varieties (Figure 3 and 4). So those varieties belong to the Group 1, whereas Red Rome van Well on stock M4 and Pink Lady on MM106 had higher carbohydrate in the leaves, assigned to the Group 2 , i.e. water requiring varieties. To Group 3 belong Gála and Galaxy on M26 stock, where the carbohydrate content did not change significantly (Figure 5)

Drought of longer duration reduced the carbohydrate content of the leaves and remained on the same level up to the beginning of ripening (August 07), whereas in Group 2, Red Rome van Well and Pink Lady the high carbohydrate content was invariable as a response to drought. The outstanding

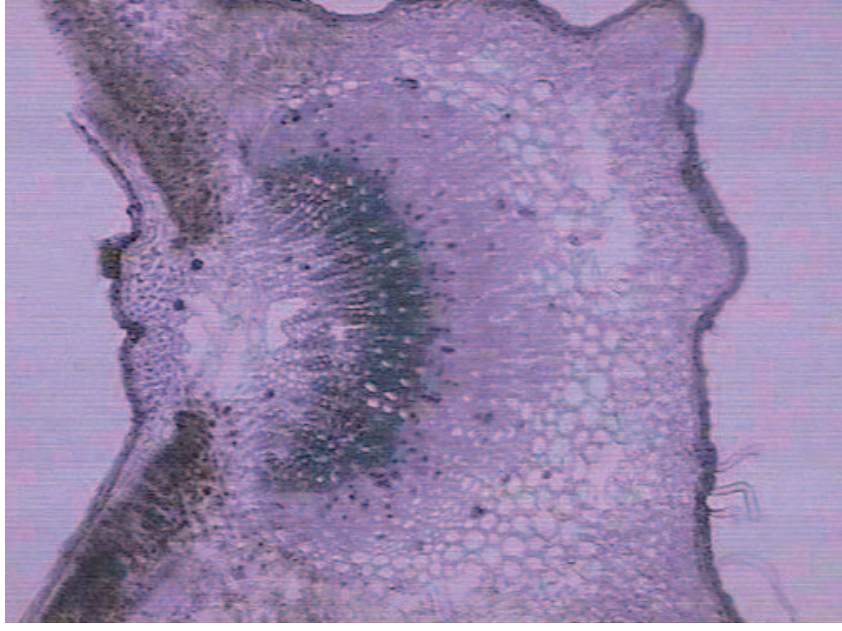

Figure 2. Cross section of the midrib of Ozark Gold leaf shows the thick cuticle of the upper epidermis. Tracheae are relatively narrow (magnification $4 \times$ )

glucose content in leaves of Galaxy was due to a heavy population of leaf aphids.

Data of 2007 and 2009 show the relatively highest chlorophyll content (SPAD) in the leaves of Idared grown on M4 stock and low density of stomata, but the weight of leaves was low because of the water stress (Table 1). In Akane and Red Rome van Well, the same SPAD caused a moderate accumulation of photosynthetic products. In Red Rome van Well, the high density of stomata increased the transpiration, but regarding the carbohydrate reaction, it is more susceptible to drought than Akane. Both varieties belong to the drought susceptible group according to their leaf morphology as well as the carbohydrate content.

Ozark Gold (M4), Galaxy (M26) displayed mediocre density of stomata and very low SPAD values meaning low accumulation rates of nutrients (organic matters) and their leaves were the lightest during the period of fruit growth. In spite of that their leaf-glucose content signalised more drought tolerance of Galaxy than that of Ozark Gold. Gála with mediocre SPAD values and mediocre density of stomata developed heavy leaves during fruit growth. It means that the organic matters accumulate (due to photosynthetic activity) and the water balance is favourable, and drought is duly counteracted.

Greensleeves on MM106 rootstock has high SPAD values, high density of stomata, heavy leaves, which proves

Table 2. Changes in the leaf structure of apple trees during fruit development under drought periods

\begin{tabular}{|c|c|c|c|c|c|c|c|c|c|c|}
\hline \multirow[t]{2}{*}{ Variety } & \multicolumn{2}{|c|}{$\begin{array}{l}\text { Leaf thickness A } \\
\text { mm }\end{array}$} & \multicolumn{2}{|c|}{$\begin{array}{c}\text { Cuticular layer A } \\
\mu \mathrm{m}\end{array}$} & \multicolumn{2}{|c|}{$\begin{array}{c}\text { Cuticular layer B } \\
\mu \mathrm{m}\end{array}$} & \multicolumn{2}{|c|}{$\begin{array}{c}\text { Leaf thickness B } \\
\mu \mathrm{m}\end{array}$} & \multicolumn{2}{|c|}{$\begin{array}{c}\text { Intercellular area B } \\
\mu \mathrm{m}^{2}\end{array}$} \\
\hline & 12 June & 24 July & 12 June & 24 July & 12 June & 24 July & 12 June & 24 July & 12 June & 24 July \\
\hline OZARK GOLD & $2.13 \mathrm{~b}$ & $2.22 \mathrm{~b}$ & $61.33 \mathrm{a}$ & $59.40 \mathrm{a}$ & $33.94 \mathrm{a}$ & $37.90 \mathrm{a}$ & $537.43 \mathrm{bc}$ & $634.70 \mathrm{a}$ & $6112.08 \mathrm{a}$ & $3367.30 \mathrm{c}$ \\
\hline IDARED & $2.19 \mathrm{~b}$ & $2.23 \mathrm{~b}$ & $58.44 \mathrm{a}$ & $59.23 \mathrm{a}$ & $33.41 \mathrm{a}$ & $36.78 \mathrm{a}$ & $564.37 \mathrm{~b}$ & $607.96 \mathrm{ab}$ & $4756.82 \mathrm{abc}$ & $2902.25 \mathrm{c}$ \\
\hline AKANE & $2.23 \mathrm{~b}$ & $2.94 \mathrm{a}$ & $49.45 \mathrm{a}$ & $62.87 \mathrm{a}$ & $35.14 \mathrm{a}$ & $37.74 \mathrm{a}$ & $500.01 \mathrm{c}$ & $567.59 \mathrm{~b}$ & $3706.02 \mathrm{c}$ & $2843.47 \mathrm{c}$ \\
\hline
\end{tabular}



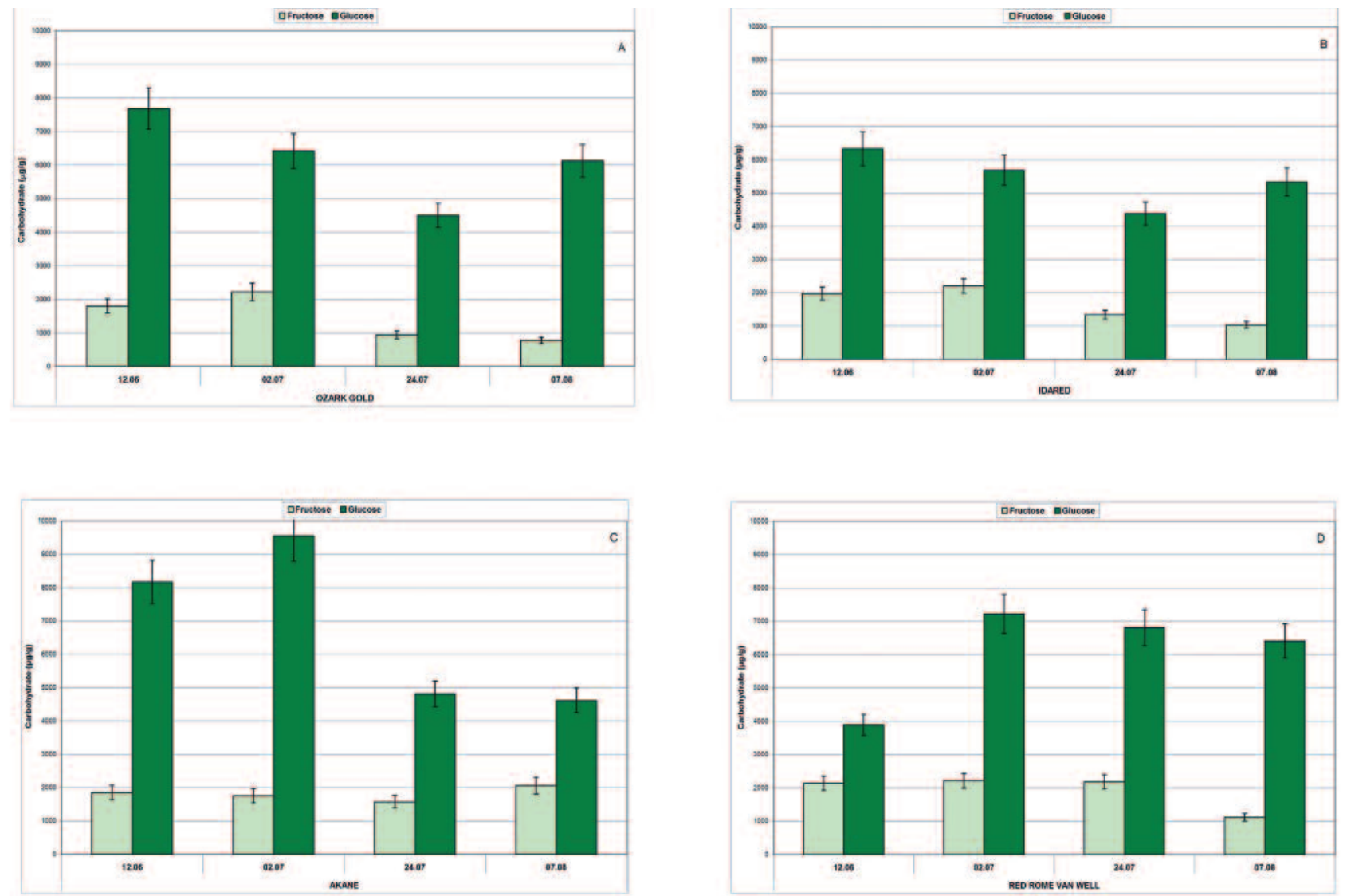

Figure 3. Effects of light drought (June 6 - July 2) and long drought period (July 24 - August 8) on varieties grafted on M4 stocks: Ozark Gold (A), Idared (B). Changes in the carbohydrate are somewhat different but similarly in Akane (C) and Red Rome van Well (D) varieties

intense uptake of nutrients and transpiration, whereas the high glucose content of leaves facilitates adequate defense against light drought periods. Pink Lady has stomata with low density, low SPAD values, which is associated with low organic matter accumulation and light leaves (small leaf weight). Also the glucose content betrays its droughtsusceptibility.

\section{Experiment II, irrigated}

The season of 2008 was rather rainy, therefore no watering was attempted at Pallag. On the contrary, 2009 was dry, and the experimental plantation received during fruit development $45 \mathrm{~mm}$ water. The drought ensued during the two successive years though at different phases of fruit growth, the signs of drought stress appeared in 2008 between June 16 and July 2; and in 2009 between July 2 and July 24.

\section{Integrated and bio(logical) growing system}

After the rainy 2008 the next year, 2009, was dry, and troubles of fertilisation appeared mainly on Jonagold and somewhat less serious on Remo and Idared in the biological block. The colour of leaves did not show any signs of drought stress, but morphological differences appeared due to high temperature and loss of water. In early May, fruits being
1-2 cm large, the leaf blades curved upwards like a spoon. The most severe curving occurred in Jonagold, the integrated and bio treatment $\left(62-60^{\circ}\right)$, the less was in Remo $\left(41-43^{\circ}\right)$. Idared leaves curved more $\left(62^{\circ}\right)$ in the integrated block than in the biological $\left(44^{\circ}\right)$. Variety Gála was present in the integrated block only, the leaves curved to $38^{\circ}$ approaching that of Remo.

In the SPAD content, there was no difference between the integrated and biological growing systems, but the mean leaf weight was higher in the bio than in the interrogated system. The dynamic approach revealed that during the fruit development the ,integrated" system produced higher SPAD values and more intense growth than the bio-system. In both years the critical period of fruit growth coincided with a drought period (July 2-July 28), where Jonagold leaves contained significantly more chlorophyll and were heavier (leaves) in the integrated than in the biological block (Table 3). During the dry, 2009, season Idared produced in the bio-system heavier leaves with higher chlorophyll content (SPAD) than in the integrated one. On the contrary the difference was inversed in the rainy season. This means that Jonagold is not suited for the biological growing system. As a technical peculiarity, we could state that in a dry year, the SPAD values did not differ between the eastern $(\mathrm{K})$ and western (NY) side of the crown, whereas in a rainy season, the eastern $(\mathrm{K})$ side produced higher SPAD values than the western side (NY). 
Table 3. Changes in the SPAD and leaf weight on different side of apple trees grown by integrated (I) and organic (B) technology ( $\mathrm{E}=$ eastern side $\mathrm{W}=$ western side, $\mathrm{S}=$ southern side of the tree $)$

\begin{tabular}{|c|c|c|c|c|c|c|c|c|c|c|c|}
\hline \multirow{3}{*}{ Date } & \multirow{3}{*}{ Growing/variety } & \multirow{2}{*}{\multicolumn{4}{|c|}{$\begin{array}{c}\mathbf{2 0 0 8} \\
\text { SPAD/side of the tree }\end{array}$}} & \multirow{3}{*}{$\begin{array}{c}\text { Leaf } \\
\text { weight } \\
(\mathrm{g})\end{array}$} & \multirow{2}{*}{\multicolumn{4}{|c|}{$\begin{array}{c}2009 \\
\text { SPAD/side of the tree }\end{array}$}} & \multirow{3}{*}{$\begin{array}{c}\text { Leaf } \\
\text { weight } \\
(\mathrm{g}) \\
\end{array}$} \\
\hline & & & & & & & & & & & \\
\hline & & $\mathrm{E}$ & $\mathrm{W}$ & $\mathrm{S}$ & SPAD átlag & & $\mathrm{E}$ & $\mathrm{W}$ & $\mathrm{S}$ & SPAD átlag & \\
\hline \multirow[t]{9}{*}{16.06} & GALA & 44.58 & 44.54 & 43.96 & $44.36 \mathrm{~h}$ & 0.96 & 41.93 & 43.49 & 42.40 & $42.61 \mathrm{~h}$ & 0.91 \\
\hline & IDARED & 50.97 & 50.60 & 50.69 & $50.76 \mathrm{~cd}$ & 0.56 & 47.90 & 44.36 & 48.18 & $46.81 \mathrm{f}^{*}$ & 0.79 \\
\hline & JONAGOLD & 49.91 & 48.65 & 51.08 & $49.88 \mathrm{~d}$ & 0.93 & 49.93 & 49.03 & 48.41 & $49.12 \mathrm{e}^{*}$ & 1.07 \\
\hline & REMO & 50.87 & 48.17 & 49.23 & $49.43 \mathrm{ed}$ & 0.67 & 49.38 & 50.88 & 47.35 & $49.20 \mathrm{e}$ & 0.63 \\
\hline & I average & 49.08 & 47.99 & 48.74 & 48.61 & 0.78 & 47.29 & 46.94 & 46.59 & 46.94 & 0.85 \\
\hline & B_IDARED & 50.94 & 50.41 & 51.78 & $51.04 \mathrm{~cd}$ & 0.82 & 49.31 & 48.51 & 47.26 & $48.36 \mathrm{e}$ & 1.00 \\
\hline & B_JONAGOLD & 48.80 & 50.21 & 48.84 & $49.28 \mathrm{ed}$ & 1.11 & 46.40 & 45.13 & 44.98 & $45.50 \mathrm{~g}$ & 1.12 \\
\hline & B_REMO & 49.20 & 49.44 & 50.34 & $49.66 \mathrm{~d}$ & 0.74 & 50.60 & 48.39 & 48.35 & $49.11 \mathrm{e}$ & 0.77 \\
\hline & B average & 49.65 & 50.02 & 50.32 & 49.99 & 0.89 & 48.77 & 47.34 & 46.86 & 47.66 & 0.96 \\
\hline \multirow[t]{9}{*}{02.07} & GALA & 45.17 & 47.04 & 44.88 & $45.70 \mathrm{~g}$ & 0.80 & 50.23 & 51.18 & 51.19 & $50.87 \mathrm{~d}$ & 0.98 \\
\hline & IDARED & 54.43 & 52.96 & 53.23 & $53.54 \mathrm{~b}^{*}$ & 0.52 & 50.52 & 49.73 & 50.32 & $50.19 \mathrm{~d}^{*}$ & 0.79 \\
\hline & JONAGOLD & 53.35 & 51.90 & 53.96 & $53.07 \mathrm{~b}^{*}$ & 0.76 & 53.76 & 55.26 & 52.81 & $53.94 \mathrm{c}^{*}$ & 1.12 \\
\hline & REMO & 54.43 & 53.74 & 50.83 & $53.00 \mathrm{~b}^{*}$ & 0.68 & 56.11 & 59.22 & 53.20 & $56.18 \mathrm{ab}$ & 0.69 \\
\hline & I average & 51.85 & 51.41 & 50.73 & 51.33 & 0.69 & 52.66 & 53.85 & 51.88 & 52.80 & 0.90 \\
\hline & B_IDARED & 49.66 & 49.21 & 49.63 & $49.50 \mathrm{ed}$ & 0.56 & 54.75 & 55.84 & 50.34 & $53.64 \mathrm{c}$ & 1.10 \\
\hline & B_JONAGOLD & 47.72 & 49.58 & 48.23 & $48.51 \mathrm{e}$ & 0.92 & 51.60 & 52.21 & 49.64 & $51.15 \mathrm{~d}$ & 1.19 \\
\hline & B_REMO & 49.93 & 47.30 & 50.34 & $49.19 \mathrm{ed}$ & 0.56 & 54.75 & 55.99 & 53.91 & $54.88 \mathrm{bc}$ & 0.78 \\
\hline & B average & 49.10 & 48.70 & 49.40 & 49.07 & 0.68 & 53.70 & 54.68 & 51.30 & 53.22 & 1.02 \\
\hline \multirow[t]{9}{*}{28.07} & GALA & 46.36 & 47.48 & 47.76 & $47.20 \mathrm{f}$ & 0.77 & 51.44 & 54.86 & 45.43 & $50.58 \mathrm{~d}$ & 0.93 \\
\hline & IDARED & 56.18 & 55.38 & 54.96 & $55.51 \mathrm{a}^{*}$ & 0.50 & 52.45 & 49.36 & 50.65 & $50.82 \mathrm{~d}^{*}$ & 0.80 \\
\hline & JONAGOLD & 55.98 & 54.28 & 54.84 & $55.03 \mathrm{a}^{*}$ & 0.76 & 56.11 & 56.71 & 51.53 & $54.78 \mathrm{c}^{*}$ & 1.11 \\
\hline & REMO & 56.69 & 55.87 & 54.13 & $55.57 \mathrm{a}^{*}$ & 0.69 & 58.16 & 61.08 & 52.12 & $57.12 \mathrm{a}^{*}$ & 0.71 \\
\hline & I average & 53.80 & 53.25 & 52.92 & 53.33 & 0.68 & 54.54 & 55.50 & 49.93 & 53.33 & 0.89 \\
\hline & B_IDARED & 52.74 & 50.94 & 50.04 & $51.24 \mathrm{c}$ & 0.92 & 54.91 & 55.58 & 50.81 & $53.77 \mathrm{c}$ & 1.02 \\
\hline & B_JONAGOLD & 51.21 & 49.81 & 50.39 & $50.47 \mathrm{~cd}$ & 0.59 & 52.52 & 53.00 & 49.67 & $51.73 \mathrm{~d}$ & 1.22 \\
\hline & B_REMO & 54.50 & 53.12 & 51.73 & $53.12 \mathrm{~b}$ & 0.61 & 56.93 & 5598 & 53.80 & $55.56 \mathrm{~b}$ & 0.81 \\
\hline & B average & 52.82 & 51.29 & 50.72 & 51.67 & 0.71 & 54.78 & 54.85 & 51.43 & 53.69 & 1.02 \\
\hline
\end{tabular}

Values in the column following different letters shows the significantly different between varieties and * between growing technology at the $\mathrm{P}<0.05$ level using Duncan's multiple range test.

The drough - reactions of apple varieties grown in the ,integrated"system

\section{Morphological changes}

Histological examination of the leaves (density of stomata, thickness of leaf-blade and cuticle), was performed on plants of the integrated growing system only. The density of stomata increased from mid of June to end of July, but the size of stomata diminished. With SPAD grew also the density of stomata intensively in Idared, Remo during the rainy season of 2008, whereas in the dry season (2009), the high density of stomata developed after a longer dry period only. In the dry year, during the critical period the density of stomata increased substantially in Idared leaves, in Remo moderately, but did not change in Jonagold.

The mean size and density of the stomata in Gála is low, whereas in Jonagold has few but large stomata (Table 4). Idared has small but many (dense) stomata

The rainy 2008 year caused no conspicuous changes in the histological structure of leaves compared with the dry
2009 year, when the thickness of the epidermis, cuticle and the intercellular space decreased and thickness of leaf increased on the half of the leaf blade. At the end of July, the thickness of the cuticle-epidermis decreased by $15 \%$ on the half of the leaf blade and by $31 \%$ along the midrib compared with the status of June. The leaf-blade became thinner along the midrib moderately $(17 \%)$ whereas there was a slight thickening (5.8\%) at the mid of the blade. The reduction of thickness in cuticle and blade as well as the intercellular spaces was most expressed in Idared leaves. The thickening of the leaf-blade was substantial in Gála and Remo as a consequence of the drought period. In Jonagold leaves, the cuticle, epidermis and leaf blade thickness was the largest among the varieties and did not change during the drought period. On the contrary, the intercellular space decreased clearly.

\section{Carbohydrate reaction of the leaves}

During the drought period, the production of carbohydrates is influenced differently on the eastern and 

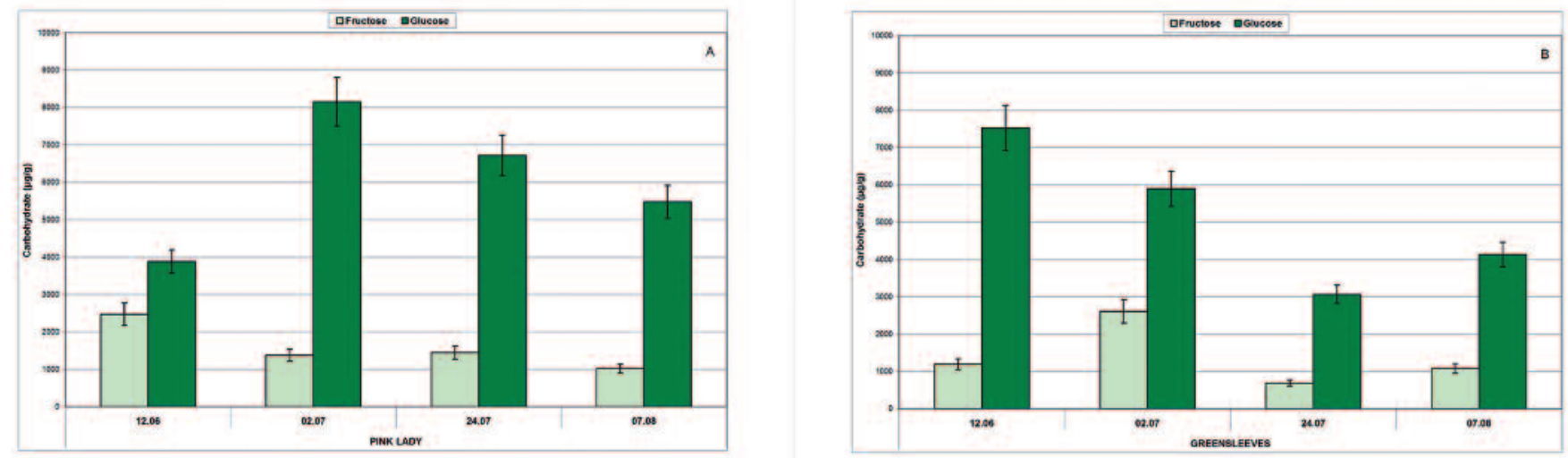

Figure 4. Effects of light drought (June 12 - July 7) and long drought period (July 24 - August 8) on MM106 stocks: Pink Lady (A) and Greensleeves (B) displayed different reactions in carbohydrate content.

Table 4. Relative chlorophyll content (SPAD) and stomata density on the leaves of apple varieties grown by integrated technology

\begin{tabular}{|c|c|c|c|c|c|c|c|c|c|}
\hline \multirow[b]{2}{*}{ Variety } & \multicolumn{3}{|c|}{2008} & \multicolumn{3}{|c|}{2009} & \multicolumn{3}{|c|}{ Average of years } \\
\hline & SPAD & $\begin{array}{c}\text { stomata } \\
\text { piece/mm² }\end{array}$ & $\begin{array}{c}\text { stomata } \\
\text { size } \mu\end{array}$ & SPAD & $\begin{array}{c}\text { stomata } \\
\text { piece/mm² }\end{array}$ & $\begin{array}{c}\text { stomata } \\
\text { size } \mu\end{array}$ & SPAD & $\begin{array}{c}\text { stomata } \\
\text { piece/mm² }\end{array}$ & $\begin{array}{c}\text { stomata } \\
\text { size } \mu\end{array}$ \\
\hline GÁLA & $45.75 \mathrm{~b}$ & $324.26 \mathrm{~b}$ & $27.55 \mathrm{ab}$ & $42.61 \mathrm{c}$ & $376.11 \mathrm{a}$ & $25.82 \mathrm{bc}$ & 44.18 & 350.19 & 26.69 \\
\hline IDARED & $53.27 \mathrm{a}$ & $367.06 \mathrm{a}$ & $26.44 \mathrm{~b}$ & $46.81 \mathrm{~b}$ & $374.67 \mathrm{a}$ & $25.22 \mathrm{c}$ & 50.14 & 370.87 & 25.83 \\
\hline JONAGOLD & $52.66 \mathrm{a}$ & $317.16 \mathrm{~b}$ & $28.14 \mathrm{a}$ & $49.12 \mathrm{a}$ & $336.49 \mathrm{~b}$ & $28.42 \mathrm{a}$ & 50.89 & 326.83 & 28.28 \\
\hline REMO & $52.66 \mathrm{a}$ & $373.10 \mathrm{a}$ & $27.78 \mathrm{ab}$ & $49.20 \mathrm{a}$ & $351.49 \mathrm{~b}$ & $25.75 \mathrm{~b}$ & 50.93 & 362.30 & 26.77 \\
\hline
\end{tabular}

Values in each column having different letters are significantly different at the $\mathrm{P}<0.05$ level using Duncan's multiple range test.

western side. The fructose content was equal, the glucose content was different. The effect of a slight drought $\left(16^{\text {th }}\right.$ day) is easier to trace with the glucose and fructose content together, than with the glucose content alone. During the early phase of fruit growth, the glucose+fructose content of leaves of the varieties Gála and Remo diminished, subsequently increased. In Idared and Jonagold leaves, the reduction of carbohydrate content was less expressed less markedly in Idared than in Jonagold. It means that Jonagold is more susceptible than Idared. That is confirmed by the fact that heavy drought caused in Jonagold leaves accumulation of considerable sucrose on three sides of the tree crown $(\mathrm{E}, \mathrm{S}, \mathrm{W})$.

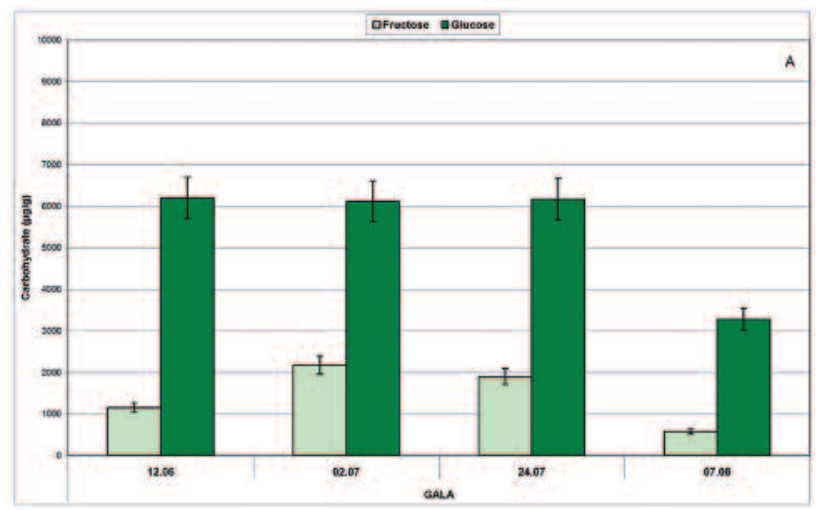

\section{Changes of antioxydant content of the leaves}

Antioxydant compounds e.g. carotenes or water soluble (ACW) and fat soluble (ACL) antioxidants have an important role in coping with drought. On the trees grown by the integrated system, the eastern and western side of the crown, chlorophyll, carotene and other antioxidants were represented equally in the different parts of the crown during the drought of the year 2009. The pigment content diminished, whereas the ACL content increased significantly due to the drought.

In the leaves of Idared, the ACW content was high, which is the sign of drought according to our earlier findings

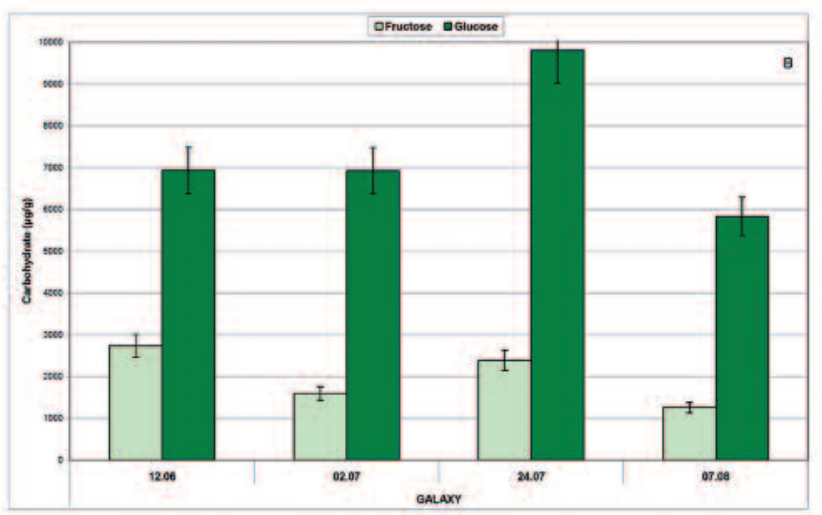

Figure 5. Gála (A) and Galaxy (B) grafted on M26 stock performed sugar reactions in light drought period (June 12 - July 7) as well as in long drought period (July 24 - August 8). 
Table 5. Changes in the chlorophyll and antioxidant content in the leaves of apple tree during fruit development in Debrecen-Pallag

\begin{tabular}{|c|c|c|c|c|c|c|c|c|c|c|}
\hline Variety & Date & $\begin{array}{c}\text { Dry matter } \\
\% \\
\end{array}$ & \begin{tabular}{|c} 
Chlorophyll \\
$\mathbf{a}$ \\
$\mathrm{mg} / \mathrm{g}$ \\
\end{tabular} & $\begin{array}{c}\text { Chlorophyll } \\
\text { b } \\
\mathrm{mg} / \mathrm{g} \\
\end{array}$ & $\begin{array}{c}\text { Chlorophyll } \\
\mathbf{a} / \mathbf{b}\end{array}$ & $\begin{array}{c}\text { Total } \\
\text { Chlorophyll } \\
\mathrm{mg} / \mathrm{g} \\
\end{array}$ & $\begin{array}{c}\text { Carotene } \\
\mathrm{mg} / \mathrm{g}\end{array}$ & $\begin{array}{c}\text { Chlorophyl1/ } \\
\text { carotene } \\
\text { ratio }\end{array}$ & $\begin{array}{l}\text { ACL* } \\
\mu \mathrm{g} / \mathrm{mg} \\
\end{array}$ & $\begin{array}{l}\mathrm{ACW}^{* * *} \\
\mu \mathrm{g} / \mathrm{mg} \\
\end{array}$ \\
\hline \multirow[t]{4}{*}{ GALA } & 09.June & $38.88 \mathrm{e}$ & $45.38 \mathrm{a}$ & $6.42 \mathrm{a}$ & 7.07 & $51.80 \mathrm{a}$ & $55.82 \mathrm{~b}$ & 0.93 & $70.52 \mathrm{ab}$ & $30.13 \mathrm{c}$ \\
\hline & 08.July & $38.52 \mathrm{e}$ & $27.97 \mathrm{~b}$ & $4.04 \mathrm{bc}$ & 6.92 & $32.00 \mathrm{bc}$ & $51.64 \mathrm{~b}$ & 0.62 & $79.25 \mathrm{a}$ & $44.96 \mathrm{c}$ \\
\hline & 23.July & $41.02 \mathrm{~d}$ & $22.90 \mathrm{c}$ & $3.25 \mathrm{c}$ & 6.92 & $25.73 \mathrm{c}$ & $61.36 \mathrm{~b}$ & 0.42 & $83.93 \mathrm{a}$ & $48.55 \mathrm{~b}$ \\
\hline & average & 39.47 & 31.95 & 4.57 & 6.97 & 36.51 & 56.27 & 0.66 & 77.90 & 41.21 \\
\hline \multirow[t]{4}{*}{ IDARED } & 09.June & $47.55 \mathrm{a}$ & $31.98 \mathrm{~b}$ & $4.51 \mathrm{~b}$ & 7.09 & $36.49 \mathrm{~b}$ & $68.94 \mathrm{~b}$ & 0.53 & $55.78 \mathrm{c}$ & $64.63 \mathrm{a}$ \\
\hline & 08.July & $44.20 \mathrm{~b}$ & $34.58 \mathrm{~b}$ & $4.80 \mathrm{~b}$ & 7.20 & $39.42 \mathrm{~b}$ & $40.41 \mathrm{c}$ & 0.98 & $73.35 \mathrm{ab}$ & $66.01 \mathrm{a}$ \\
\hline & 23.July & $45.25 \mathrm{~b}$ & $24.70 \mathrm{c}$ & $3.50 \mathrm{c}$ & 7.06 & $28.19 \mathrm{c}$ & $57.51 \mathrm{~b}$ & 0.49 & $95.85 \mathrm{a}$ & $70.23 \mathrm{a}$ \\
\hline & average & 45.67 & 30.42 & 4.27 & 7.12 & 34.7 & 55.62 & 0.67 & 74.99 & 66.96 \\
\hline \multirow[t]{4}{*}{ JONAGOLD } & 09.June & $43.00 \mathrm{~b}$ & $37.35 \mathrm{a}$ & $5.23 \mathrm{a}$ & 7.14 & $42.58 \mathrm{a}$ & $61.11 \mathrm{~b}$ & 0.70 & $49.11 \mathrm{c}$ & $46.69 \mathrm{bc}$ \\
\hline & 08.July & $42.67 \mathrm{bc}$ & $20.23 \mathrm{c}$ & $2.79 \mathrm{c}$ & 7.25 & $23.01 \mathrm{c}$ & $23.46 \mathrm{~d}$ & 0.98 & $70.13 \mathrm{ab}$ & $51.20 \mathrm{~b}$ \\
\hline & 23.July & $42.30 \mathrm{c}$ & $27.48 \mathrm{~b}$ & $3.87 \mathrm{bc}$ & 7.10 & $31.35 \mathrm{bc}$ & $94.03 \mathrm{a}$ & 0.33 & $78.30 \mathrm{a}$ & $53.64 \mathrm{~b}$ \\
\hline & average & 42.66 & 28.35 & 3.96 & 7.16 & 32.31 & 59.53 & 0.67 & 65.85 & 50.51 \\
\hline \multirow[t]{4}{*}{ REMO } & 09.June & $41.20 \mathrm{~d}$ & $45.08 \mathrm{a}$ & $6.33 \mathrm{a}$ & 7.12 & $51.40 \mathrm{a}$ & $55.72 \mathrm{bc}$ & 0.92 & $69.56 \mathrm{ab}$ & $36.72 \mathrm{c}$ \\
\hline & 08.July & $42.13 \mathrm{c}$ & $28.30 \mathrm{~b}$ & $3.98 \mathrm{bc}$ & 7.11 & $32.28 \mathrm{bc}$ & $43.29 \mathrm{c}$ & 0.75 & $76.09 \mathrm{a}$ & $43.01 \mathrm{c}$ \\
\hline & 23.July & $43.66 \mathrm{~b}$ & $25.69 \mathrm{bc}$ & $3.57 \mathrm{c}$ & 7.20 & $29.26 \mathrm{c}$ & $68.87 \mathrm{~b}$ & 0.42 & $78.67 \mathrm{a}$ & $45.46 \mathrm{bc}$ \\
\hline & average & 42.33 & 33.02 & 4.63 & 7.14 & 37.65 & 55.96 & 0.70 & 74.77 & 41.73 \\
\hline
\end{tabular}

* ACL $=$ Antioxidant Capacity of Lipid soluble substance

** ACW= Antioxidant Capacity of Water soluble substance

Values in each column having different letters are significantly different at the $\mathrm{P}<0.05$ level using Duncan's multiple range test.

(Nemeskéri et al. 2008). In Jonagold, the leaves contain initially few ACL antioxidants, which increases during the drought (July $8-23$ ) and signalises the defence against high temperature and radiation (Table 5). Jonagold performed similarly as Idared regarding ACL production. In Gála and Remo, the high ACL and the low ACW content did not change during drought, which means that they are armed against water loss and excessive heath.

The changes in antioxydant content of leaves during the dry season of 2009 confirmed the distinction of groups attempted on data of the previous season. Jonagold leaves contain few water soluble antioxydants (ACW), but with the increased ACL content, it saves the plant from the heath stress. Jonagold leaves display high SPAD values, they are large with low density of stomata. This indicates the susceptibility to drought. Idared leaves contain though more antioxidants (ACL, ACW) than Jonagold, the dry matter content and thin cuticle assign it to the group of drought susceptible varieties. In Gála and Remo leaves, the ACL content did not change during the drought period of fruit growing, so the varieties are armed with an effective system of defence against drought.

\section{Discussion}

Lack of moisture, high temperature and intense radiation destroy the chlorophyll content of the leaves, which impairs the photosynthetic activity. Yadava (1986) stated a tight correlation between the SPAD values and the content of chlorophyll. The SPAD (relative chlorophyll content) and photosynthesis $(\mathrm{Pn})$ are closely related $(\mathrm{r}=0.804)$ as stated by Kato et al. (2004), and similarly between net photosynthesis and conductivity of stomata (França et al. 2000, Kato et al. 2004). If SPAD values of leaves are 40-44, Pn is around 16-20 associated with $0.75-1.0$ values of conductivity of stomata (Kato et al. (2004). We supposed that in the field, SPAD measurements will indicate the water utilisation of apple varieties or their relative drought resistance. In our experiments, the increasing SPAD values of apple leaves were paralleled by higher density of stomata during the drought period of fruit growth, but the latter changed variably depending on the water requirement of varieties. On the site without irrigation, tight and significant correlation $(\mathrm{r}=0.67)$ characterised the relation between SPAD and density of stomata indicating a moderate susceptibility to drought (Gála, Galaxy on M26 rootstock), where the values SPAD increased up to 42 , the density of stomata decreased. Under those conditions, no significant relation between SPAD and the density of stomata could be proved neither on varieties grown on M4 and MM106 rootstocks, which coincides with the statements of Gomes et al (2004), as the drought resistance of the rootstocks is able to compensate the deleterious effects of a short drought period. The weight of leaves in Idared grown on M4 stock increased if SPAD values increased beyond 50, in Ozark Gold the weight of leaves diminished till 42 SPAD values during the drought. The leaf structure of Ozark Gold, as in the cross section of the midrib the low number of small tracheae and the thickness of the intercellular sheet impaired the water supply of the leaves.

Under conditions of the advantageous humidity in 2008, the correlation between SPAD and density of stomata was 
tight ( $\mathrm{r}=0.9104)$ in the moderately drought susceptible group of varieties (Gála, Remo/M26), but the significance was $\mathrm{P}=10 \%$ only. In the water-dependent group (Idared, Jonagold) the correlation was very tight $(r=0.9448)$ and significant at $P=5 \%$, which is underlined by the spoon-like deformation of leaves. In the water-dependent group, the values of SPAD and the density of stomata increased. Regardless of the season, the relative chlorophyll content of leaves (SPAD) was tightly correlated with the mean weight of leaves $(r=0.6929$ and $r=0.6219)$ in both groups grafted to M4 or M26 rootstocks. Our results prove that the supply of nutrients and of water produced tight correlation between SPAD and leaf weight ( $\mathrm{r}=0.9197)$ but only in the moderately drought susceptible group of varieties, where within the interval 44-52 of SPAD values caused the reduction of leaf weight. In the water-requiring group of varieties this correlation is not significant $(\mathrm{r}=0.5273)$.

Other authors (Griffin et al. 2004) stated that the high sucrose and glucose content of leaves defends the plant efficiently against strong irradiation and degradation of chlorophyll. Although the correlation between SPAD and glucose content of the leaves was tight $(r=0.7539)$, the significance was low $(\mathrm{P}=10 \%)$ in the water-requiring varieties.

Apple varieties belonging to this group reacted sensitively to water loss in a short drought period by increasing the synthesis of carbohydrates and of antioxidant compounds. During longer dry periods (42 days), the carbohydrate content of the leaves diminished and the antioxidants increased in the leaves of the moderately drought resistant group of varieties (Greensleeves and Idared) (Nemeskéri et al. 2009).

The antioxidant content of leaves on the eastern and western side of the tree crown did not differ substantially in spite of the defence mechanism of the trees displayed was variable. In the drought hit season of 2009, the fat soluble (ACL) antioxidant content on the eastern side of the trees increased during the ripening of fruits (June 9-July 23), especially in the varieties Idared and Jonagold. As in members of the water dependent group (Idared and Jonagold), on the eastern part of the crown, contents of SPAD and ACL antioxidants the correlation was tight ( $\mathrm{r}=0.889)$ but only at a low significance $(\mathrm{P}=10 \%)$. In the humid season of 2008, the eastern part of the trees showed tight correlation between SPAD and ACL contents $(r=0.71)$, and between ACL and fruit yield ( $\mathrm{kg} /$ tree), which was significant $(\mathrm{r}=0.72)$. The ACL content of leaves increases when SPAD is more than 45 , but at the same time, the yield $(\mathrm{kg} / \mathrm{tree})$ diminishes significantly.

In apple leaves, the majority of water-soluble antioxidants is represented by ascorbic acid. Its increasing content is a sign of active adaptation during the 15-dayslasting drought period. However, a heavy drought causes the diminution of ascorbic acid content (Sircelj et al. 2007). In the drought hit season of 2009, SPAD and ACW content was closely correlated $(r=0.736)$ in the water-requiring group (Idared, Jonagold) only, which means that SPAD values above 50 is associated by decreasing ACW values.
In the integrated block, results of two seasons prove the tight and significant correlation between SPAD content and the weight of leaves $(r=0.76, r=0.88)$ in varieties Gála and Remo. Increasing photosynthesis causes an increment in the accumulation of organic compounds first in the leaves. As an opposite, significant correlation $(r=0.63)$ was found in Idared, where the increasing SPAD was coupled with decreasing leaf weight, which is the sign of troubles in nutrient- and water-uptake. Gála and Remo displayed high ACL content, which did not change during the growth of fruits neither through the drought period. Those varieties are armed with a highly efficient defence system.

\section{Conclusion}

SPAD measurements in the field may trace the accumulation of organic matters, which is documented with the increasing leaf weights being correlated $(r=0.76-r=0.88)$, but it depends also on the variety. The relative chlorophyll content (SPAD), as indicating water transport and combined with observing density of stomata cannot be used for the recognition of water-requiring varieties, but for the preliminary identification of tolerant varieties. In the integrated system, the water soluble antioxidant (ACW) content diminished if the SPAD values were higher than 50 .

In irrigated (at Pallag) and non irrigated (at Újfehértó) experiments, the Gála variety grafted on M26 stock showed 42-45 SPAD values and intermediate densities of stomata (320-350 db/mm ${ }^{2}$, which proves the balance of organic matter accumulation and water supply, confirmed also by changes in glucose and antioxidant contents. All those indicate the presence of a defence mechanism of high level against heath-stress. Without irrigation, Idared grown on M4 stock produced leaves with increasing weight as a function of SPAD if its values were higher than 50. At the same time, on rootstock M26 the leaf weight decreased. In the "integrated" assortment of varieties, changes registered in the morphology, histology as well as SPAD and antioxidant content of leaves facilitated the distinction of varieties as belonging to groups of different degrees of waterrequirement or drought tolerance. Gála and Remo are rated as "less susceptible to drought", Idared and Jonagold on the other hand as "drought susceptible".

In the non irrigated plantation of Újfehértó, the following varieties are found to be drought susceptible: Akane, Red Rome van Well, Pink Lady. Those varieties reacted intensely to short periods of drought by increasing the carbohydrate and antioxidant content of leaves. On the basis of changes in carbohydrate content of leaves Greensleeves and Ozark Gold are assigned to the group of moderately water requiring varieties.

\section{References}

Caspari, H.W., Einhorn, T.C., Leib, Preston, K. Andrews, B.G., Redulla, C.A., Lombardini, L., Auvil T. \& McFerson, J.R. (2004): Progress in the development of partial rootzone drying of apple trees. Acta Horticulturae, 664: 125-132. 
Berzsenyi, Z. \& Lap, D.Q. (2003): A N-mütrágyázás hatása a kukorica- (Zea mays L.) hibridek szemtermésére és N-mütrágyareakciójára tartamkísérletben (Effect of $\mathrm{N}$ fertilisation on the grain yield and $\mathrm{N}$ fertiliser response of maize (Zea mays $\mathrm{L}$.) hybrids in a long-term experiment) Növénytermelés, 52 (3-4): 389-407.

Eghball, B. \& Maranville, J.W. (1991): Interactive effects of water and nitrogen stresses on nitrogen utilization efficiency, leaf water status and yield of corn genotypes. Commun. Soil. Sci. Plant Anal., 22:1367-1382

Fanizza, G., Ricciardi, L. \& Bagnulp, C. (1991): Leaf greenness measurements to evaluate water stressed genotypes in Vitis vinifera. Euphytica, 55 (1): 27-31.

França-Costa, M.G., Pham-Thi, A.T., Pimentel, C., PereyraRossiello, R.O., Zuily-Fodil, Y. \& Laffray, D. (2000): Differences in growth and water relations among Phaseolus vulgaris cultivars in response to induced drought stress. Environ. Exp. Botany, 43: 227-237.

Gomes, A.M.M., Lagoa, A.M.M.A., Medina, C.L., Machado, E.C. \& Machado, M.A. (2004): Interactions between leaf water potential, stomatal conductance and abscisic acid content of orange trees submitted to drought stress. Braz. J. Plant Physiol., 16 (3): 155-161.

Green, S.R., Vogeler, I., Clothier, B.E., Mills, T.M. \& C.van den Dijssel (2003): Modeling water uptake by a mature apple tree. Aust. J. Soil Res., 41 (3): 365-380.

Griffin, J.J., Ranney, T.G. \& Pharr, D.M. (2004): Photosynthesis, chlorophyll fluorescence, and carbohydrate content of Illicium Taxa grown under varied irradiance. J. Amer. Soc. Hort. Sci., 129 (1): 46-53.

Jones, H.G. (2007): Monitoring plant and soil water status: established and novel methods revisited and their relevance to studies of drought tolerance. J. Exp. Botany, 58 (2): 119-130.

Kato, M., Kobayashi, K., Ogiso, E. \& Yokoo, M. (2004): Photosynthesis and dry-matter production during ripening stage in a female-sterile line of rice. Plant Prod. Sci., 7 (2):184-188

Kusnyirenko, M.D. (1981): A gyümölcsfák vízforgalmának és szárazságtűrésének élettana. Mezőgazda Kiadó Pudapest.

Nemeskéri, E., Remenyik, J. \& Fári, M. (2008): Studies on the drought and heat stress response of green bean (Phaseolus vulgaris
L.) varieties under phytotronic conditions. Acta Agron. Hung., 56 (3): 321-328.

Nemeskéri, E., Sárdi, É., Kovács-Nagy, E., Stefanovits Bányai, É., Nagy, J., Nyéki, J. \& Szabó, T. (2009): Studies on the drought responses of apple trees (Malus domestica Borkh.) grafted on different rootstocks Int. J. Hortic. Sci. in Hungary, 15 (1-2): 29-36

Ommen, O.E., Donnelly, A., Vanhoutvin, S., Oijen, M. \& Manderscheid, R. (1999): Chlorophyll content of spring wheat flag leaves grown under elevated $\mathrm{CO} 2$ concentrations and other environmental stresses within the 'ESPACE-wheat' project. Eur. J. Agron., 10: 197-203.

Pastenes, C., Pimentel, P. \& Lillo, J. (2005): Leaf movements and photoinhibition in relation to water stress in field-grown beans. J. Exp. Bot., 56 (411): 425-433.

Perry, E.M. \& Davenport, J.R. (2007): Spectral and spatial differences in response of vegetation indices to nitrogen treatments on apple. Computers and Electronics In Agriculture, 59: 56-65.

Sárdi, É., Velich, I., Hevesi, M. \& Klement, Z. (1999): Ontogenesis-and biotic stress dependent variability of carbohydrate content in snap bean (Phaseolus vulgaris L.). Z. Naturforsch., 54c: 782-787.

Šircelj, H., Tausz, M., Grill, D. \& Batič, F. (2005): Biochemical responses in leaves of two apple tree cultivars subjected to progressing drought. J. Plant Physiol., 162: 1218-1308.

Šircelj, H., Grill, D. \& Bati, F. (2007): Detecting different levels of drought stress in apple trees (Malus domestica Borkh.) with selected biochemical and physiological parameters. Sci. Hort., 113 (4): 362-369.

Wang, Z.C. \& Stutte, G.W. (1992): The role of carbohydrates in active osmotic adjustment in apple under water stress. J. Amer. Soc. Hortic. Sci., 17 (5): 816-823.

Wang, Z. Quebedeaux, B. \& Stutte, G.W. (1996): Partitioning of [C-14] glucose into sorbitol and other carbohydrates in apple under water stress. Austr. J. Plant Physiol., 23 (3): 245-251.

Yadava, U.L. (1986): A rapid and nondestructive method to determine chlorophyll in intact leaves. HortScience, 21 (6): 1449-1450.

Zatykó I. (2003): Az alma aszályérzékenységének tényezői. (In Hungarian) Kertgazdaság, 35 (1): 33-39. 